\title{
URGENSI PENEGAKAN HUKUM HAK CIPTA TERHADAP PEMBUAT KONTEN DALAM PENGGUNAAN LAGU DI MEDIA SOSIAL
}

\author{
Langit Rafi Soemarsono, Rianda Dirkareshza \\ Fakultas Hukum Universitas Pembangunan Nasional Veteran Jakarta, Jakarta \\ langitrafis@upnvj.ac.id
}

\begin{abstract}
Abstrak
Tulisan ini bertujuan untuk mengkaji dan meneliti terkait bagaiamana penegakan hukum terhadap para pembuat konten dalam penggunaan lagu di media sosial. Metode penelitian hukum yuridis normatif dengan pendekatan analisis dengan menggunakan ketentuan perundang-undangan yang relevan dengan permasalahan yang dibahas. Hasil studi menunjukkan bahwa salah satu fenomena yang cukup sering ditemukan di internet khususnya di berbagai platform media sosial adalah pelanggaran hak cipta yang dilakukan oleh para pembuat konten dalam penggadaan ulang dan mempublikasikan karya cipta lagu milik pencipta lagu atau musisi, tanpa menyadari pentingnya aturan hak ekonomi dan hak moral terkait hak cipta lagu. Akibat maraknya pelanggaran yang terjadi mengenai hak cipta khususnya mengenai lagu, tidak sedikit peran dari para musisi ataupun pencipta lagu yang menginginkan pembaharuan terkait peraturan hak cipta khususnya dalam penggunaan karya lagu di media sosial. Adapun dalam penelitian ini akan membahas tentang apa bentuk pelanggaran hak cipta yang dilakukan oleh para pembuat konten dalam penggunaan lagu di media sosial dan bagaimana bentuk penegakan hukum bagi para pembuat konten dalam penggunaan lagu media sosial. Bahwa berdasarkan hasil analisis, dapat ditarik kesimpulan menjadi penting untuk dibuat dalam peraturan pemerintah yang secara spesifik mengenai ketentuan hak cipta dalam penggunaan lagu di media sosial yang kaitannya dengan hak ekonomi dan hak moral.
\end{abstract}

Kata kunci: Hak Cipta; Lagu; Penegakan Hukum

\section{THE URGENCE OF COPYRIGHT LAW ENFORCEMENT ON CONTENT MAKERS IN USING SONG ON SOCIAL MEDIA}

\begin{abstract}
This paper aims to examine and examine how the law is enforced against content creators in the use of songs on social media. The normative juridical legal research method uses an analytical approach using the provisions of the legislation that are relevant to the issues discussed. The results of the study show that one of the phenomena that is quite often found on the internet, especially on various social media platforms, is copyright infringement committed by content creators in reproducing and publishing copyrighted songs belonging to songwriters or musicians, without realizing the importance of the rules of economic and social rights. moral rights related to song copyright. Due to the rampant violations that occur regarding copyright, especially regarding songs, there are not a few roles of musicians or songwriters who want reforms related to copyright regulations, especially in the use of song works on social media. As for in this study, it will discuss what forms of copyright infringement are carried out by content creators in the use of songs on social media and how the form of law enforcement for content creators in the use of social media songs. That based on the results of the analysis, it can be concluded that it is important to make government regulations specifically regarding copyright provisions in the use of songs on social media which are related to economic rights and moral rights.
\end{abstract}

Keywords: Copyright; Songs; Law Enforcement 


\section{A. PENDAHULUAN}

Penegakan hukum dalam penggunaan lagu mengenai hak cipta lagu di Indonesia masih menjadi fenomena yang cukup hangat untuk dibahas. Implementasi terkait substansi hukum hak cipta lagu menjadi relevan untuk dibicarakan. Dalam aspek hukum menjadi penting untuk dibahas karena pada praktiknya perlindungan hukum secara preventif tidak cukup dalam mengatasi sengketa terkait pelanggaran hak cipta lagu. Disisi lain seiring dengan perkembangan teknologi banyak orang yang melakukan penggadaan ulang dan mempublikasikan karya cipta lagu milik orang lain di platform media sosial khususnya di Instagram, TikTok, dan YouTube tanpa menyadari pentingnya menerapkan aturan hak ekonomi dan hak moral terkait hak cipta lagu. ${ }^{1}$ Selain itu, akibat maraknya pelanggaran yang terjadi mengenai hak cipta khususnya mengenai lagu, banyak para musisi ataupun pencipta lagu yang menginginkan pembaharuan terkait peraturan hak cipta khususnya dalam penggunaan karya lagu di media sosial. ${ }^{2}$ Kendati pun demikian pemerintah sendiri belum mempunyai regulasi khusus mengenai mekanisme cover version atau membawakan ulang lagu milik orang lain di media sosial.

Hak cipta merupakan suatu hak yang eksklusif sebagaimana halnya dalam ketentuan hak cipta lagu. Artinya, setiap orang atau pelaku usaha yang menggunakan ciptaan lagu untuk suatu kepentingan dan kegiatan komersial yang dilakukan di berbagai tempat seperti kafe, hotel, restoran dan lain nya harus meminta izin terlebih dahulu kepada pencipta nya atau pun kepada pemegang hak cipta nya yang sah, karena hak yang eksklusif hanya ditujukan bagi pencipta nya dan tidak satu pun dari pihak lain yang dapat mengambil manfaat ekonomi tanpa izin pencipta atau pemegang hak cipta nya yang sah. Faktanya dalam suatu kajian tertentu mengenai hak cipta dijelaskan bahwa tingkat pelanggaran hak cipta di Indonesia masih sangat tinggi, hingga termasuk sepuluh besar negara pembajak hak cipta di dunia. ${ }^{3}$ Walaupun dalam perlindungannya hak cipta secara jelas diatur mulai dari hak esensial yang terkandung di dalam sebuah ciptaan. ${ }^{4}$

Berdasarkan Pasal 1 angka (1) Undang-Undang No. 28 tahun 2014 tentang Hak Cipta merumuskan bahwa hak cipta adalah hak eksklusif pencipta yang timbul secara otomatis berdasarkan prinsip deklaratif setelah suatu ciptaan diwujudkan dalam bentuk nyata tanpa mengurangi pembatasan sesuai dengan ketentuan peraturan perundangundangan. Undang-Undang No. 28 tahun 2014 tentang Hak Cipta menetapkan kriterianya adalah "penggunaan secara komersial" yaitu pemanfaatan ciptaan dan/atau produk hak

${ }^{1}$ Rianda Dirkareshza, Dinda Maurizka Azura, and Roni Pradana, "Kebijakan Pemerintah Di Masa Pandemi Covid-19: Antara Negara Sejahtera Dan Negara Sehat," Jurnal Mercatoria 1, no. 1 (2021): 79-98, http://ojs.uma.ac.id/index.php/mercatoria/article/view/731/643.

${ }^{2}$ Hulman Panjaitan, "Akibat Hukum Penggunaan Karya Cipta Musik Dan Lagu Tanpa Izin,” To-Ra 6, No. 3 (2020): 290-301.

${ }^{3}$ Munawar Akhmad and Effendy Taufik, "Upaya Penegakan Hukum Planggaran Hak Cpta Menurut UndangUndang Nomor 28 Tahun 2014 Tentang Hak Cipta,” Journal of Chemical Information and Modeling 53, no. 9 (2016): 1689-99.

4 Atiekah Achmad and Kholis Roisah, "Status Hukum Ghostwriter Dan Pemegang Hak cipta Dalam Plagiarisme Menurut Undang-Undang Hak cipta,” Jurnal Magister Hukum Udayana (Udayana Master Law Journal) 9, no. 2 (2020): 429-47, https://doi.org/10.24843/JMHU.2020.v09.i02.p.15. 
terkait dengan tujuan untuk memperoleh keuntungan ekonomi dari berbagai sumber atau berbayar. Dalam konteks penggunaan karya cipta lagu atau oleh pihak lain untuk kegiatan usaha yang bersifat komersial yang menurut UU No. 28 Tahun 2014 tentang Hak Cipta disebut dengan "penggunaan secara komersial" wajib hukumnya menurut undang-undang untuk meminta izin terlebih dahulu dari pencipta dan atau pemegang hak cipta. Pemberian izin dimaksud dilakukan dalam bentuk pemberian lisensi, yang menurut Pasal 1 angka (20) UU No. 28 Tahun 2014 tentang Hak Cipta merupakan izin tertulis yang diberikan oleh pemegang hak cipta atau pemilik hak terkait kepada pihak lain untuk melaksanakan hak ekonomi atas ciptaan nya atau produk hak terkait dengan syarat tertentu.

Fadhila (2018) dalam penelitiannya yang berjudul "Perlindungan Karya Cipta Lagu Dan/Atau Musik Yang Dinyanyikan Ulang (Cover Song) Di Jejaring Media Sosial Dikaitkan Dengan Hak Ekonomi Berdasarkan Undang-Undang Nomor 28 Tahun 2014 Tentang Hak Cipta”, mengangkat permasalahan perlindungan hukum terkait perilaku cover version yang diunggah di media sosial. ${ }^{5}$ Berdasarkan Pasal 8 Undang-Undang Hak Cipta dijelaskan bahwa penggunaan karya cipta lagu yang dinyayikan ulang (cover version) di media sosial bukanlah suatu pelanggaran hak moral bila tidak melakukan perubahan ciptaan dan bukan untuk kepentingan komersial. Sebaliknya dikatakan melanggar hak ekonomi jika diperuntukkan untuk kegiatan yang sifatnya mendatangkan keuntungan komersial dengan tidak melakukan izin dari pencipta dalam konteks menggunakan lagu milik orang lain. Komersialisasi pada suatu karya ciptaan menjadi permasalahan utama, khususnya pada cover version. Pelanggaran terhadap sebuah ciptaan akan dikesampingkan apabila bertujuan untuk pembuatan karya ilmiah, kritik, dan juga pendidikan. Kendati demikian tetap menjadi perhatian bersama bagi para pembuat konten dan masyarakat untuk memahami masalah komersialisasi dari konten yang melibatkan lagu milik orang lain di media sosial.

Penelitian sebelumnya oleh Aini (2021) yang berjudul "Pemenuhan Prinsip Fair Use Dalam Cover Lagu Berdasar Hukum Hak Cipta Indonesia”, mengangkat permasalahan ketentuan prinsip fair use dalam persoalan cover version ditinjau dari hukum hak cipta yang berlaku. ${ }^{6}$ Ketentuan hak cipta telah melindungi lagu dan/atau musik sebagaimana diatur dalam Pasal 40 huruf d Undang-Undang Hak Cipta. Bahwa perilaku cover version dapat menyebabkan pelanggaran terhadap hak cipta dikarenakan menyalahkan ketentuan hak moral dan hak ekonomi dari pencipta lagu. Contohnya rawan terjadi modifikasi, merekam, dan mengaransemen. Di sisi lain penggunaan wajar terkait cover lagu dapat meningkatkan popularitas pencipta, apabila para pelaku cover version mencantumkan nama pencipta lagu selaku pemiliki hak cipta. Adapun fokus pada

${ }^{5}$ Ghaesany Fadhila and U. Sudjana, "Perlindungan Karya Cipta Lagu Dan/Atau Musik Yang Dinyanyikan Ulang (Cover Song) Di Jejaring Media Sosial Dikaitkan Dengan Hak ekonomi Berdasarkan Undang-Undang Nomor 28 Tahun 2014 Tentang Hak Cipta," Acta Diurnal Jurnal Ilmu Hukum Kenotariatan Dan Ke-PPAT-An 1, no. 2 (2018): 222, https://doi.org/10.24198/acta.v1i2.117.

${ }^{6}$ Fatimah Nurul Aini and Indirani Wauran, "Pemenuhan Prinsip Fair Use Dalam Cover Lagu Berdasar Hukum Hak Cipta Indonesia ( Fair Use Principles in Cover Song Based on Indonesian Copyright Law ) Abstrak,” no. 28 (2021): 707-28. 
penelitian ini yaitu ditekankan prinsip fair use sebagaimana merupakan aturan yang harus ditegakkan sepenuhnya.

Pada jurnal yang ditulis oleh Dewi (2017) dengan judul "Perlindungan Hukum Hak Cipta Terhadap Cover Version Lagu Di Youtube”, mengangkat permasalahan mengenai ketentuan hukum cover version yang diunggah pada platform YouTube. ${ }^{7}$ Dalam melakukan cover version lagu milik orang lain dan menggunggahnya ke media sosial YouTube bukanlah merupakan suatu bentuk pelanggaran hak cipta apabila pembuatan dan pengumuman tersebut dilakukan dengan tidak melanggar hak-hak ekslusif pemegang hak cipta. Mengacu pada Pasal 43 huruf d Undang-Undang Hak Cipta "perbuatan yang tidak dianggap sebagai pelanggaran Hak Cipta meliputi: pembuatan dan penyebarluasan konten Hak Cipta melalui media teknologi informasi dan komunikasi yang bersifat tidak komersial dan/ atau menguntungkan Pencipta atau pihak terkait, atau Pencipta tersebut menyatakan tidak keberatan atas pembuatan atau penyebarluasan tersebut”. Walaupun demikian perlindungan hukum terhadap pemegang hak cipta atas pelanggaran hak cipta di bidang musik dan lagu dalam bentuk cover version yang dikomersilkan dapat dilakukan melalui dua cara yaitu upaya preventif dan upaya represif. Bahwa upaya preventif sebagaimana diatur dalam Pasal 66-67 Undang-Undang tentang Hak Cipta sedangkan itu upaya represif melalui penyelesaian sengketa arbitrasi atau pengadilan. Penelitian ini lebih membahas dari sisi perlindungan hukum yang secara kurang efektif dari segi preventif dan juga represif. Namun, dengan tujuan bersama memberikan saran bagi pemerintah untuk memberikan regulasi yang terbaru terkait aturan hak cipta lagu.

Berdasarkan penelitian yang telah dilakukan sebelumnya, maka dapat diperoleh gambaran secara umum bahwa penegakkan hukum hak cipta dalam penggunaan lagu di media sosial telah diatur dalam ketentuan Undang-Undang No 28 Tahun 2014 tentang Hak Cipta dengan memuat aturan yang mengikat didalamnya berupa unsur hak ekonomi dan hak moral. Apabila para pembuat konten menggunakan lagu milik orang lain dan mengunggahnya di media sosial maka sudah seharusnya mengaplikasikan kedua unsur tersebut. Hal tersebut dikarenakan para pembuat konten telah memiliki banyak pengikut di media sosial, aktif mengandung iklan dibeberapa unggahannya yang dengan untuk kepentingan komersil. Namun yang menjadi kekurangan pada penelitain-penelitian tersebut adalah hanya mengambil contoh kasus dari satu platform media sosial saja saja misalnya YouTube. Sedangkan, pada penelitian ini mencoba menggali berbagai fenomena penggunaan lagu yang dilakukan oleh para pembuat konten dari aplikasi Instagram, TikTok, dan juga YouTube.

Penelitian ini dimaksudkan untuk memberikan suatu perspektif yang berbeda dalam upaya penegakan hukum hak cipta lagu di media sosial dengan cara yang spesifik menjawab dua pertanyaan: Pertama, apa bentuk pelanggaran hak cipta yang dilakukan oleh para pembuat konten dalam penggunaan lagu di media sosial. Kedua, bagaimana penegakan hukum terhadap tindakan para pembuat konten terkait pelanggaran dalam

${ }^{7}$ Anak Agung Mirah Satria Dewi, "Perlindungan Hukum Hak Cipta Terhadap Cover Version Lagu Di Youtube," Jurnal Magister Hukum Udayana (Udayana Master Law Journal) 6, no. 4 (2017): 508, https://doi.org/10.24843/jmhu.2017.v06.i04.p09. 
penggunaan lagu di media sosial. Pada kenyataannya terdapat berbagai bentuk pelanggaran yang dilakukan oleh para pembuat konten di berbagai platform media sosial dengan mengabaikan aturan hak cipta lagu. Dan penting untuk memahami bentuk perlindungan hukum yang sebagaimana diatur dalam Undang-Undang Nomor 28 Tahun 2014 tentang Hak Cipta.

Tulisan ini didasarkan pada sebuah argumen bahwa pencipta lagu kurang mendapat perlindungan hukum terkait ak cipta lagu dan apresiasi dari para pembuat konten dalam penggunaan lagu di media sosial. Walaupun telah diberlakukannya ketentuan UndangUndang Nomor 28 Tahun 2014 tentang Hak Cipta masih menimbulkan problematika tersendiri bagi pencipta atau pemegang hak cipta lagu. Bahwa bentuk pelanggaran yang dilakukan oleh para pembuat konten dalam penggunaan lagu media sosial tidak boleh dibiarkan begitu saja, tentunya hal tersebut harus didukung dengan peraturan perundangundangan mampu memberikan perlindungan hak cipta lagu khususnya di media sosial secara spesifik sehingga cara preventif sebagai bentuk pencegahan berjalan sesuai dengan ketentuan hukum yang ada. Berdasarkan permasalahan diatas, penelitian ini bertujuan untuk memberikan kepastian hukum dan mengkaji perspektif normatif mengenai penegakan hukum terhadap para pembuat konten dalam penggunaan lagu di media sosial.

\section{B. PERMASALAHAN}

Berdasarkan latar belakang yang telah dijelaskan sebelumnya, adapun rumusan masalah penelitian ini antara lain; Pertama, apa bentuk pelanggaran hak cipta yang dilakukan oleh para pembuat konten dalam penggunaan lagu di media sosial? kedua, bagaimana penegakan hukum terhadap tindakan para pembuat konten terkait pelanggaran dalam penggunaan lagu di media sosial?

\section{METODE PENELITIAN}

Fenomena hukum yang terjadi terkait pelanggaran hak cipta di Indonesia masih menjadi isu yang cukup penting khususnya bagi para pencipta atau pemilik hak cipta lagu. Hal tersebut dikarenakan masih banyak terjadi pelanggaran dalam penggunaan lagu di media sosial yang dilakukan oleh para pembuat konten. Pada kenyataannya penegakan hukum terkait ruang lingkup hak cipta lagu belum terlaksana dengan baik, terlebih dibutuhkan regulasi baru secara spesifik. Adapun selain dari sisi penegakan hukum penting juga untuk dikaji untuk meningkatkan apresiasi para pembuat konten dalam menghargai karya cipta lagu milik orang lain khususnya para pencipta lagu.

Penelitian ini dilakukan dengan menggunakan metode yuridis normatif. Metode yuridis normatif merupakan metode penelitian hukum yang dilakukan dengan cara meneliti bahan pustaka atau bahan sekunder belaka. ${ }^{8}$ Adapun penelitian hukum ini menggunakan data kualitatif yang bersifat primer dan sekunder. Data sekunder merupakan bahan-bahan hukum primer dan sekunder. Data sekunder tersebut terdiri dari 2 (dua) sumber bahan hukum, yaitu bahan hukum primer berupa perundang-undangan atau hukum positif yang berlaku di Indonesia, yaitu Undang-Undang Nomor 28 Tahun

${ }^{8}$ Henni Muchtar, "Analisis Yuridis Normatif Sinkronisasi Peraturan Daerah Dengan Hak Asasi Manusia," Humanus 14, no. 1 (2015): 80, https://doi.org/10.24036/jh.v14i1.5405. 
2014 tentang Hak Cipta dan bahan hukum sekunder berupa sumber-sumber pustaka, seperti jurnal, skripsi, tesis.

Pengumpulan data yang dilakukan adalah melalui studi kepustakaan, dengan merujuk pada sumber-sumber pustaka secara digital dan cetak. Sumber digital terdiri dari sumber yang berasal dari berbagai artikel atau jurnal dan media sosial khususnya Instagram, TikTok dan YouTube yang dapat diakses melalui daring. Terkait pemilihan sumber-sumber tersebut dilakukan dengan mempertimbangkan keterkaitan pembahasan dan bersifat kredibel. Selain itu. Sumber cetak merupakan jenis buku-buku bidang hukum dan buku-buku bidang ilmu lainnya. Sumber-sumber tersebut dipilih dengan tujuan memiliki relevansi terhadap suatu topik penulisan.

Teknik Analisis dalam tulisan ini berbentuk deskriptif kualitatif. Teknik Analisis ini dilakukan dengan cara memilih topik-topik yang memiliki keterkaitan terhadap berbagai sumber rujukan yang ditemukan dan diterjemahkan untuk menjelaskan pentingnya perlindungan hukum terkait hak cipta lagu terhadap para pencipta atau pemilik hak cipta lagu di Indonesia. Khususnya dalam hal mengkaji sudut pandang normatif dalam upaya penegakan hukum terhadap pembuat konten dalam penggunaan lagu di media sosial dan juga meningkatkan pemahaman masyarakat terhadap hak cipta lagu.

\section{HASIL DAN PEMBAHASAN}

\section{Bentuk Pelanggaran Hak Cipta Yang Dilakukan Para Pembuat Konten Dalam Penggunaan Lagu Di Media Sosial}

Konten cover song atau membawakan kembali lagu milik orang lain memang menjadi hal yang cukup populer di berbagai platform media sosial misalnya YouTube, Instagram ataupun TikTok. Didukung oleh kemudahan teknologi dan informasi yang semakin berkembang mengakibatkan para pembuat konten menjadi lebih mudah dalam berkarya. Namun, disisi lain dengan adanya kemudahan tersebut para pembuat konten seringkali mengabaikan aturan hukum terkait cover song yang telah diatur dalam ketentuan Undang-Undang No. 28 Tahun 2014 tentang Hak Cipta. Adapun hal-hal yang melatarbelakangi para pembuat konten melakukan pelanggaran hak cipta yaitu, para pembuat konten belum menyadari aturan hukum terkait hak cipta lagu, para pembuat konten dengan sengaja tidak mengikuti aturan hukum terkait hak cipta lagu dan kurangnya penegakkan hukum terkait pelanggaran hak cipta lagu. Bahwa hal-hal tersebut saling berkaitan dan dapat dikatakan sebagai faktor pemicu terjadinya pelanggaran terkait cover song yang dilakukan oleh para pembuat konten di berbagai platform media sosial seperti yang telah terjadi Di Indonesia.

Pada tahun 2017 banyak orang yang membawakan ulang lagu berjudul "Akad" milik group musik Payung Teduh. Salah satu sosok yang membawakan ulang lagu akad dengan jumlah penonton yang banyak adalah Hanin Dhiya. Ia dikenal cukup sering membuat konten cover version di platform YouTube dan sering kali videonya ditonton lebih dari 1 juta penonton. Bahkan lagu "Akad" versinya lebih banyak ditonton 
dibandingkan dengan jumlah penonton di akun YouTube payung teduh. Tidak hanya itu, Hanin juga mempublikasikan karyanya dalam berbagai layanan streaming yang tentunya mengandung kepentingan komersil di dalamnya. Namun, yang jadi permasalahan tindakan tersebut dilakukan oleh Hanin tanpa seizin pihak Payung Teduh. Alhasil, Hanin Dhiya mendapat teguran keras dari pihak Payung Teduh yang mengatakan bahwa ada baiknya untuk meminta izin terlebih dahulu ketika ingin membawakan lagu miliknya, dalam hal ini mereka menginginkan karya nya di apresiasi oleh siapapun. Kendati pun permasalahan ini telah dimanfaatkan oleh berbagai kalangan musisi dan pencipta lagu untuk menyuarakan pendapatnya bahwa memahami hak cipta dari hasil karya lagu milik orang lain adalah penting. ${ }^{9}$

Selain itu, pada awal tahun 2021 kasus mengenai hak cipta lagu media sosial juga terjadi pada platform TikTok dimana PT Digital Rantai Maya menggugat TikTok dan ByteDance sebesar Rp 13,1 miliar ke Pengadilan Negeri (PN) Jakarta Pusat. Gugatan tersebut diketahui atas dugaan pelanggaran hak cipta lagu dari Virgoun Teguh Putra. Dikutip dari laman Sistem Informasi Penelusuran Perkara Pengadilan Negeri Jakarta Pusat, penggugat dalam hal ini PT Digital Rantai Maya menggugat ByteDance. Inc dan TikTok.PTE LTD dengan nomor perkara 4/Pdt.Sus-HKI/Cipta/2021/PN Niaga Jkt.Pst. PT Digital Rantai Maya mengajukan gugatan materiil sebesar Rp 3,1 miliar terkait tanpa izin melakukan penggandaan, pengedaran, dan penyebaran lagu-lagu pada master rekaman. Salah satu poin petitum di antaranya tentang perjanjian kerja sama PT Digital Rantai Maya dengan Virgoun Teguh Putra tentang Label Produk Rekaman No. DRM: Legal/DRM/055/X/2015 tertanggal 3 Nopember 2015 adalah sah. Adapun proses hukum yang saat ini dilakukan adalah menunggu sidang pertama dijadwalkan pada 22 april 2021. Namun, hingga saat ini belum terdapat informasi lebih lanjut mengenai perkembangan kasus ini. ${ }^{10}$

Pada platform Instagram pun fenomena mengenai lemahnya penegakan hukum hak cipta masih dapat ditemukan. Misalnya unggahan dari akun Instagram bernama awkarin sebagai pembuat konten yang sudah terverifikasi oleh pihak Instagram, mempunyai kepentingan komersil pada beberapa unggahannya dan memiliki sebanyak 7 juta, dimana pada salah satu video yang diunggahnya pada tanggal 10 Agustus 2021 telah menggunakan lagu berjudul "Best Friend" yang dinyanyikan oleh Saweetie bersama Doja Cat namun yang menjadi permasalahan adalah awkarin tidak mencantumkan nama penyanyi ataupun judul pada unggahan tersebut. ${ }^{11}$ Selain itu, pada jenis kasus yang sama dapat kita liat pada akun Instagram bernama aldy maldini seorang penyanyi, sekaligus pembuat konten di Instagram yang sudah terverifikasi (centang biru), memiliki 1.5 juta pengikut dan aktif memasarkan produk iklan pada laman Instagram miliknya. Dalam salah satu video unggahannya pada tanggal 21 juni 2021 yang berisikan cuplikan Aldy

\footnotetext{
${ }^{9}$ Amrikh Palupi, “Cover 'Akad' Diprotes, Hanin Dhiya Minta Maaf,” Dream.co.id, 2017, https://www.dream.co.id/showbiz/cover-akad-diprotes-hanin-dhiya-ucapkan-permohonan-maaf-171010u.html.

10 Wahyunanda Kusuma Pertiwi, "TikTok Digugat Rp 13,1 Miliar Terkait Hak Cipta Lagu Virgoun," Kompas.com, 2021, https://tekno.kompas.com/read/2021/01/26/16140037/tiktok-digugat-rp-13-1-miliar-terkait-hakcipta-lagu-virgoun.

${ }^{11}$ Awkarin, "That My Bestfriend,” Instagram.com, 2021, https://www.instagram.com/p/CSYiAwxJ3-J/.
} 
Maldini menyanyikan lagu berjudul "Mirrors" milik Justin Timberlake namun tidak mencantumkan nama penyanyi maupun judul lagu tersebut. ${ }^{12}$

Pada hakikatnya menyiarkan, membawakan lagu orang lain di media sosial bukanlah sesuatu yang melanggar hukum, menjadi pelanggaran apabila hal itu dilakukan tanpa ada kesepakatan kedua belah pihak yaitu antara pihak yang membawakan ulang dan menyiarkan lagu dengan pencipta atau pemegang hak cipta yang lagunya digunakan dinyanyikan kemudian mendapatkan manfaat ekonomi dari hal tersebut. ${ }^{13}$ Bahwa untuk tidak melanggar hak cipta orang lain, untuk mereproduksi, merekam, mendistribusikan sebuah lagu milik orang lain dengan tujuan komersial, seseorang perlu memperoleh izin dari pencipta atau pemegang hak cipta. Perbuatan yang dilakukan oleh Hanin Dhiya, pihak TikTok dan juga para pembuat konten di platform Instagram tidak dapat dibenarkan karenamerupakan suatu tindakan pelanggaran terhadap hak cipta. Hal tersebut tidak sejalan dengan prinsip hak ekonomi yaitu melanggar pembatasan-pembatasan yang terdapat dalam ketentuan Undang-Undang Hak Cipta Nomor 28 Tahun 2014 tentang Hak Cipta. Bahwa untuk tidak melanggar hak cipta orang lain, untuk mereproduksi, merekam, mendistribusikan sebuah lagu milik orang lain dengan tujuan komersial, seseorang perlu memperoleh izin dari pencipta atau pemegang hak cipta.

Sehubungan adanya bukti kasus yang telah dijelaskan diatas dapat dikatakan praktik yang sedang berjalan masih menimbulkan polemik dalam ruang lingkup hak cipta lagu. Di mana dengan adanya pelanggaran terkait urusan meng-cover lagu di media sosial dapat dikatakan bahwa Undang-Undang tentang Hak Cipta Tahun 2014 tidak lah cukup untuk memberikan perlindungan hukum kepada para pencipta lagu pencipta lagu dalam kasus tersebut sangatlah dirugikan karena perilaku Hanin Dhiya yang melanggar ketentuan hak ekonomi yang mana sudah seharusnya pencipta lagu mendapatkan keuntungan komersil dari cover version yang dilakukan oleh Hanin di platform media sosial. Hanin sudah seharusnya meminta izin untuk mendapatkan lisensi kepada pemilik hak cipta terlebih dahulu dalam hal ini dari pihak payung teduh sebelum melakukan cover karena memang ketentuan di Undang-Undang Hak Cipta seperti itu. Jika saja Hanin melakukan rangkaian proses lisensi dan sebagainya, tentu tidak akan menjadi kasus seperti sekarang dan justru akan mendatangkan keuntungan royalti bagi kedua belah pihak karena yang dilakukan hanin sudah sah secara hukum. ${ }^{14}$

Perilaku dari pihak TikTok pun sudah sepatutnya tidak boleh dibenarkan dalam bentuk apapun, walaupun pada akhirnya pihak virgoun telah menempuh jalur hukum tetapi dalam hal ini hanya memberikan teguran khususnya kepada TikTok. Bahwa Virgoun sendiri menginginkan kepada setiap orang untuk dapat menghargai karya musisi dalam kaitannya membuat konten di media sosial. Bentuk dari apresiasi yang dilakukan yaitu dengan menerapkan hak ekonomi dan hak moral. Sedangkan itu terkait perilaku

\footnotetext{
${ }^{12}$ Aldy Maldini, “Sedikit Video Keseruan Live Streaming Kemarin Di @bartspacejakarta Hehe Thank u Untuk Semua Yang Sudah Nonton Ya!!!!!, Instagram.com, 2021, https://www.instagram.com/p/CQYUseGhNwi/.

${ }^{13}$ Agus Dimyati, "Tinjauan Yuridis Terhadap Perlindungan Hak Cipta Dalam Penggunaan Karya Cipta Musik Dan Lagu Karaoke,” Hukum Responsif Jurnal Hukum 7, no. 1 (2018): 30-43.

${ }^{14}$ Dewa Gede Jeremy Zefanya and A.A Sri Indrawati, "Cover Lagu Milik Musisi Indonesia” 8, no. 28 (2020): $1908-17$.
} 
para pembuat konten di platform Instagram yang melanggar aturan hak cipta sebagaimana yang telah dicontohkan diatas bahwa sudah seharusnya mereka menerapkan hak atribusi yang dalam hal ini mengharuskan identitas pencipta dietakan pada ciptaan, baik dengan nama diri maupun samara dan dalam hal-hal tertentu dan atas dasar pertimbangan dari pencipta, pencipta dapat meniadakan identitas dirinya dan membiarkan ciptaanya berstatus anonim. ${ }^{15}$

Berkaca pada kasus Hanin Dhiya, kasus virgoun pada aplikasi TikTok dan bentuk pelanggaran hak cipta di media sosial yang dilakukan oleh para pembuat konten menandakan masih terdapat bukti permasalahan hak cipta dalam praktik yang sedang berjalan. Pada kenyataanya pencipta masih belum mendapatkan perlindungan hukum yang serius terkait hak cipta dari pemerintah. Hak ekonomi yang sebagaimana melekat pada ketentuan undang-undang tapi dalam praktik yang sedang berjalan ini masih menimbulkan konflik. ${ }^{16}$ Bahwa pemerintah haruslah bertindak sesegera mungkin dalam menangani permasalahan terkait hak cipta khsususnya dalam lingkup di media sosial. sehubungan dengan itu sudah seharusnya jika para pelaku cover version ini menerapkan kedua hak yang menjadi bagian dalam hak cipta tersebut sebagaimana dicantumkan dalam undang-undang hak cipta. Bahwa pelaku cover version apabila dalam kontennya telah mengandung unsur komersil maka harus mendapatkan izin terlebih dahulu kepada para pencipta atau publisher dan apabila pelaku cover version dalam kontennya tidak mendatangkan keuntungan komersil, yang dalam hal ini hanya sebagai bentuk apresiasi saja maka cukup untuk mencantumkan identitas dari lagu yang ingin dibawakan ulang.

\section{Upaya Penegakan Hukum Bagi Para Pembuat Konten Dalam Penggunaan Lagu Di Media Sosial}

Seiring diberlakukannya ketentuan Undang-Undang Nomor 28 Tahun 2014 tentang Hak Cipta menimbulkan problematika tersendiri bagi pencipta atau pemegang hak cipta terkhusus terhadap pencipta lagu. Pada kenyataannya fenomena yang terjadi dalam masyarakat masih banyak ditemukan pelanggaran terhadap hak ekonomi dan hak moral yang seharusnya dimiliki secara eksklusif oleh pencipta atau pemegang hak cipta. ${ }^{17}$ Dalam hal ini banyak pengguna dalam mempergunakan karya lagu yang tidak memiliki tanggung jawab dikarenakan penggunaan tersebut tidak didasari oleh dasar hukum yang kuat yaitu berupa izin dari pencipta atau pemegang hak cipta. Saat ini pengawasan dalam arti memberikan perlindungan hukum terhadap para pengguna yang dalam mempergunakan karya lagu dari hasil ciptaan orang lain baik dalam kegiatan-kegiatan yang berhubungan dengan hak ekonomi pencipta atau pemegang hak cipta dan hak moral

${ }^{15}$ I Gusti Putu Andre Pratista and Ida Ayu Sukihana, "Pelanggaran Hak Moral Karya Lagu / Musik Dan Rekaman Suara Dalam Praktik Penggunaan Hak," n.d., 1-5.

${ }^{16}$ Akhmad and Taufik, "Upaya Penegakan Hukum Planggaran Hak Cpta Menurut Undang-Undang Nomor 28 Tahun 2014 Tentang Hak Cipta."

${ }^{17}$ Ayup Suran Ningsih and Balqis Hediyati Maharani, "Penegakan Hukum Hak Cipta Terhadap Pembajakan Film Secara Daring," Jurnal Meta-Yuridis 2, no. 1 (2019): 13-32, https://doi.org/http://dx.doi.org/10.26877/my.v2i1.3440. 
pencipta atau pemegang hak cipta tersebut. ${ }^{18}$ Hal ini dilakukan untuk meminimalisir tindak pelanggaran terhadap hak cipta lagu khususnya yang terjadi di media sosial.

Di sisi lain perlindungan hukum secara represif ditujukan untuk membuat efek jera atau hukuman kepada para pengguna yang melanggar hak cipta. ${ }^{19}$ Namun, hal tersebut tidak lah cukup untuk memberikan regulasi terkait perilaku cover version terhadap karya cipta lagu terutama di media sosial. ${ }^{20}$ Hal ini dikarenakan pada tahun 2014 persoalan meng-cover lagu tidak begitu ramai perbincangkan. Saat ini pada kenyataannya belum secara eksplisit diatur mengenai mekanisme cover lagu terutama di media sosial. Kendati pun demikian pemerintah baru saja mengeluarkan Peraturan Pemerintah Republik Indonesia Nomor 56 Tahun 2021 Tentang Pengelolaan Royalti Hak cipta Lagu, peraturan tersebut diciptakan untuk menjamin pelindungan dan kepastian hukum terhadap hak ekonomi pencipta, pemegang hak cipta, dan pemilik hak terkait atas lagu dan/atau musik, dengan adanya mekanisme pengelolaan royalti yang transparan, berkualitas, melalui sarana teknologi informasi. Pengelolaan royalti juga dilakukan oleh Lembaga Manajemen Kolektif Nasional sebagai suatu lembaga yang berwenang berdasarkan undang-undang yang merepresentasikan keterwakilan dari kepentingan pencipta dan pemilik hak terkait untuk menarik, menghimpun, dan mendistribusikan royalti dari orang yang melakukan penggunaan secara komersial. Namun, peraturan tersebut hanya memfokuskan kepada performing rights bukan terhadap pengelolaan royalti di media sosial. ${ }^{21}$

Pada kenyataanya ketentuan Undang-Undang Nomor 28 Tahun 2014 tentang Hak Cipta masih menimbulkan isu serius bagi pencipta atau pemegang hak cipta terkhusus terhadap pencipta karya lagu. ${ }^{22}$ Bahwa perlindungan hukum terkait hak cipta atas karya lagu tidak terlaksana dengan baik, hal ini dikarenakan peraturan perundang-undangan tidak mampu untuk memberikan perlindungan khusus sehingga cara preventif sebagai bentuk pencegahan tidak berjalan sesuai dengan peraturan perundang-undangan. ${ }^{23}$ Walaupun dalam peraturan tersebut telah memperoleh perlindungan secara preventif karena dengan adanya ketentuan undang-undang tentang hak cipta yang telah berlaku hingga saat ini, belum dapat memberikan jaminan terhadap terlindunginya hak eksklusif. Pada dasarnya ketentuan umum mengenai hak cipta yang dijelaskan dalam Pasal 1 angka 1 Undang-Undang tentang Hak cipta bahwa hak cipta merupakan hak eksklusif pencipta yang timbul secara otomatis berdasarkan prinsip deklaratif setelah suatu ciptaan diwujudkan dalam bentuk nyata.

\footnotetext{
${ }^{18}$ Muh Habibi, Akbar Rusly, and Mukti Fajar Nd, "Mekanisme Pembayaran Royalti Lagu Dan Musik Dalam Aplikasi Streaming Musik" 1 (2020): 81-94, https://doi.org/10.18196/mls.v1i2.8344.

${ }^{19}$ I Gusti Putu Agung Angga Aditya and Anak Agung Ketut Sukranatha, "Perlindungan Hak Terkait Sehubungan Dengan Cover Version Lagu Berdasarkan Undang-Undang Hak Cipta," Kertha Semaya : Journal Ilmu Hukum 7, no. 1 (2019): 1, https://doi.org/10.24843/km.2018.v07.i01.p07.

${ }^{20}$ Habi Kusno, "Perlindungan Hukum Hak Cipta Terhadap Pencipta Lagu Yang Diunduh Melalui Internet," FIAT JUSTISIA:Jurnal Ilmu Hukum 10, no. 3 (2017): 489-502, https://doi.org/10.25041/fiatjustisia.v10no3.789.

${ }^{21}$ J. Sinaga, “Jurnal Ilmiah Kebijakan Hukum,” Jurnal Ilmiah Kebijakan Hukum 10, no. 2 (2020): 1-209.

${ }^{22}$ Muhammad Dwi Adriansyah, Pengaturan Pemberian Royalti Atas Hak Cipta Aransemen Lagu Di Indonesia Dan Amerika Serikat, 2021.

${ }^{23}$ Situmeang Ampuan and Kusmayanti Rita, "Perlindungan Hukum Terhadap Pencipta Atau Pemegang Hak Cipta Lagu Dalam Pembayaran Royalti," Journal of Law and Policy Transformation 53, no. 9 (2020): 1689-99.
} 
Berdasarkan Pasal 4 Undang-Undang tentang Hak Cipta, terdapat 2 (dua) bentuk hak bersifat eksklusif yang berada di bawah perlindungan hak cipta, yaitu hak moral dan hak ekonomi. Hak eksklusif yang dimaksud disini menurut Penjelasan Pasal 4 UndangUndang tentang Hak Cipta adalah hak yang hanya diperuntukkan bagi pencipta, sehingga tidak ada pihak lain yang dapat memanfaatkan hak tersebut tanpa izin pencipta. Pemegang hak cipta yang bukan Pencipta hanya memiliki sebagian dari hak eksklusif berupa hak ekonomi. ${ }^{24}$ Sedangkan itu bentuk dari hak moral yang terdapat di dalam Pasal 5 UU Hak Cipta adalah:

a) Tetap mencantumkan atau tidak mencantumkan namanya pada salinan sehubungan dengan pemakaian ciptaannya untuk umum;

b) Menggunakan nama aliasnya atau samarannya;

c) Mengubah ciptaannya sesuai dengaan kepatutan dalam masyarakat;

d) Mengubah judul dan anak judul ciptaan; dan

e) Mempertahankan haknya dalam hal terjadi distorsi ciptaan, mutilasi ciptaan, modifikasi ciptaan, atau hal yang bersifat merugikan kehormatan diri atau reputasinya. $^{25}$

Adapun aturan hak ekonomi yaitu hak untuk mendapatkan manfaat ekonomi atas ciptaan serta produk hak terkait. Pada lagu, hak ekonomis yang didapat oleh pencipta misalnya dari royalti pengumuman dan perbanyakan lagu tersebut, disamping itu hak moralnya berkaitan dengan dilekatkannya nama pencipta pada lagu tersebut dan hak untuk mempertahankan (termasuk mengubah) lagu ciptaannya. ${ }^{26}$ Sesuai ketentuan Pasal 9 ayat (1) Undang-Undang No. 28 tahun 2014 tentang Hak Cipta, hak ekonomi yang dimaksdudkan terdiri dari :
a. Penerbitan Ciptaan
b. Penggandaan Ciptaan dalam segala bentuknya
c. Penerjemahan Ciptaan
d. Pengadaptasian, pengaransemenan atau pentransformasian Ciptaan
e. Pendistribusian Ciptaan atau salinannya
f. Pertunjukan Ciptaan
g. Pengumuman Ciptaan
h. Komunikasi Ciptaan; dan
i. Penyewaan Ciptaan.

Dapat dikemukakan bahwa pelaksanaan hak perbanyakan atau penggandaan Di Indonesia belum optimal, hal ini terbukti dari banyaknya pelanggaran yang terjadi, bentuk-bentuk pelanggaran hak tersebut seperti praktik pembajakan. Upaya penegakan hukum sudah mulai dilakukan, bahkan ada kasus yang sampai ke tingkat pengadilan,

\footnotetext{
${ }^{24}$ Fadhila and Sudjana, "Perlindungan Karya Cipta Lagu Dan/Atau Musik Yang Dinyanyikan Ulang (Cover Song) Di Jejaring Media Sosial Dikaitkan Dengan Hak Ekonomi Berdasarkan Undang-Undang Nomor 28 Tahun 2014 Tentang Hak Cipta."

${ }^{25}$ Aini and Wauran, "Pemenuhan Prinsip Fair Use Dalam Cover Lagu Berdasar Hukum Hak Cipta Indonesia ( Fair Use Principles in Cover Song Based on Indonesian Copyright Law ) Abstrak."

${ }^{26}$ M. Zulfa Aulia and Isran Idris, "Hak Cipta Dan Eksploitasi Ciptaan Lagu Daerah Kerinci: Perspektif Pencipta," Masalah-Masalah Hukum 49, no. 4 (2020): 420-31, https://doi.org/10.14710/mmh.49.4.2020.420-431.
} 
namun dirasakan belum maksimal dan belum sesuai dengan rasa keadilan masyarakat. Berdasarkan Pasal 44 Undang-Undang tentang Hak Cipta mengatur sebagai berikut Pasal 44

(1) Penggunaan, pengambilan, Penggandaan, dan/atau pengubahan suatu Ciptaan dan/atau produk Hak Terkait secara seluruh atau sebagian yang substansial tidak dianggap sebagai pelanggaran Hak cipta jika sumbernya disebutkan atau dicantumkan secara lengkap untuk keperluan:

1. pendidikan, penelitian, penulisan karya ilmiah, penyusunan laporan, penulisan kritik atau tinjauan suatu masalah dengan tidak merugikan kepentingan yang wajar dari Pencipta atau Pemegang Hak cipta;

2. keamanan serta penyelenggaraan pemerintahan, legislatif, dan peradilan;

3. ceramah yang hanya untuk tujuan pendidikan dan ilmu pengetahuan; atau

4. pertunjukan atau pementasan yang tidak dipungut bayaran dengan ketentuan tidak merugikan kepentingan yang wajar dari Pencipta.

Mengenai penjelasan diatas, maka seseorang yang ingin membuat cover version cukup mencantumkan sumber lagu yg ingin di cover yaitu berupa nama penyanyi, pencipta judul dsb. Hal demikian ditujukan sebagai bentuk hak untuk diakui terhadap penyanyi yang ingin karya nya kita cover serta dalam konteks ini tidak perlu membutuhkan izin lebih lanjut kepada publishing sebagai mana melihat ketentuan diatas. Seseorang wajib mendapat kan izin dari publishing atau pencipta lagu tersebut. Sebab, apabila seseorang yang ingin membuat cover lagu di YouTube tanpa izin akan dikenakan denda pidana yang diatur dalam ketentuan pidana Undang-Undang Nomor 28 tahun 2014 tentang Hak Cipta sebagaimana dalam Pasal 112 Ayat (1) yang menjelaskan bahwa :

(1)'Setiap Orang yang dengan tanpa hak melakukan perbuatan sebagaimana dimaksud dalam Pasal 7 ayat (3) dan/atau Pasal 52 untuk Penggunaan Secara Komersial, dipidana dengan pidana penjara paling lama 2 (dua) tahun dan/atau pidana denda paling banyak Rp300.000.000,00 (tiga ratus juta rupiah)."

Lalu, dalam Pasal 113 Ayat (1), (2), (3), dan (4) juga dijelaskan bahwa:

(1)“Setiap Orang yang dengan tanpa hak melakukan pelanggaran Hak ekonomi sebagaimana dimaksud dalam Pasal 9 ayat (1) huruf $i$ untuk Penggunaan Secara Komersial dipidana dengan pidana penjara paling lama 1 (satu) tahun dan/atau pidana denda paling banyak Rp100.000.000 (seratus juta rupiah)."

(2) "Setiap Orang yang dengan tanpa hak dan/atau tanpa izin Pencipta atau pemegang Hak cipta melakukan pelanggaran Hak ekonomi Pencipta sebagaimana dimaksud dalam Pasal 9 ayat (1) huruf c, hurufd, huruff, dan/atau huruf $h$ untuk Penggunaan Secara Komersial dipidana dengan pidana penjara paling lama 3 (tiga) tahun dan/atau pidana denda paling banyak Rp500.000.000,00 (lima ratus juta rupiah)."

(3) "Setiap Orang yang dengan tanpa hak dan/atau tanpa izin Pencipta atau pemegang Hak cipta melakukan pelanggaran hak ekonomi Pencipta 
sebagaimana dimaksud dalam Pasal 9 ayat (1) huruf a, huruf b, huruf e, dan/atau huruf g untuk Penggunaan Secara Komersial dipidana dengan pidana penjara paling lama 4 (empat) tahun dan/atau pidana denda paling banyak Rp1.000.000.000,00 (satu miliar rupiah)."

(4) "Setiap Orang yang memenuhi unsur sebagaimana dimaksud pada ayat (3) yang dilakukan dalam bentuk pembajakan, dipidana dengan pidana penjara paling lama 10 (sepuluh) tahun dan/atau pidana denda paling banyak Rp4.000.000.000,00 (empat miliar rupiah)."

Selain itu, terdapat juga upaya pencegahan dari sisi hukum yaitu berdasarkan ketentuan Pasal 66-67 Undang-Undang No. 28 Tahun 2014 tentang Hak Cipta yaitu: Pasal 66

(1) "Pencatatan Ciptaan dan produk Hak Terkait diajukan dengan Permohonan secara tertulis dalam bahasa Indonesia oleh Pencipta, Pemegang Hak Cipta, pemilik Hak Terkait, atau Kuasanya kepada Menteri."

(2) "Permohonan sebagaimana dimaksud pada ayat (1) dilakukan secara elektronik dan/atau non elektronik dengan:

a. menyertakan contoh Ciptaan, produk Hak Terkait, atau penggantinya;

b. melampirkan surat pernyataan kepemilikan Ciptaan dan Hak Terkait;dan c. membayar biaya."

Pasal 67

(1) "Dalam hal Permohonan sebagaimana dimaksud dalam Pasal 66 ayat (1) diajukan oleh:

a. beberapa orang yang secara bersama-sama berhak atas suatu Ciptaan atau produk Hak Terkait, Permohonan dilampiri keterangan tertulis yang membuktikan hak tersebut; atau

b. badan hukum, Permohonan dilampiri salinan resmi akta pendirian badan hukum yang telah disahkan oleh pejabat berwenang."

Berdasarkan isi kedua pasal tersebut pada intinya menjelaskan pentingnya dilakukan pencatatan terhadap setiap hasil ciptaan atau dalam konteks pembahasan ini hasil karya cipta lagu. Di samping itu, selain dari sisi hukum upaya pencegahan juga dapat dilakukan dari kesadaran diri masing-masing dari para pembuat konten untuk saling menghargai karya cipta milik orang lain. Bahwa pentingnya menjaga suatu ekosistem dalam hal ini industri musik dengan cara tidak melanggar ketentuan hak cipta lagu yang dimulai dari niat dalam diri sendiri karena, membuat suatu karya cipta lagu itu tidak mudah perlu pengetahuan, keterampilan, kemampuan, dan juga kreativitas yang mumpuni. Perlu diketahui bahwa hak cipta itu merupakan hak yang melekat ketika karya cipta itu diciptakan, sehingga menjadi sangat penting untuk dilindungi dan diapresiasi secara baik. Apabila niat awal dari para pembuat konten saja sudah keliru dengan mengabaikan ketentuan hukum maka akan berdampak buruk pada si pencipta lagu atau dalam skala besar dapat menghambat kemajuan industri musik di tanah air. 
Adapun Peraturan Pemerintah Republik Indonesia Nomor 56 Tahun 2021 tentang Pengelolaan Royalti Hak Cipta Lagu Dan/Atau Musik yang secara khusus lebih berfokus pada penerapan performing rights. Dalam hal ini sebagai langkah awal transparansi upaya pemberlakuan royalti bagi setiap musisi yang lagu-lagunya diputar di tiap restoran, kafe, hingga hotel. Bahwa pemerintah juga harus membuat peraturan pemerintah terkait pengelolaan royalti yang terkhusus pada hak ekonomi dan hak moral terkait hak cipta lagu di media sosial. Misalnya, apabila nantinya pusat data lagu digital yang direncanakan oleh pemerintah telah diciptakan, maka mekanisme mengenai ketentuan cover version terkait hak ekonomi akan efektif untuk diterapkan kepada masyarakat. Sehingga, apabila seseorang ingin melakukan cover version yang dapat mendatangkan keuntungan komersil maka tinggal mendaftar di aplikasi digital terkait lagu yang ingin dimainkan. Dapat dikatakan jika para pelaku mengikuti mekanisme tersebut maka kesejahteraan para pencipta lagu dapat terpenuhi dengan mendapatkan hak nya dan para pelaku cover juga telah secara sah legal dalam membuat cover version di media sosial.

\section{E. PENUTUP}

Dengan ditemukannya berbagai bentuk pelanggaran hak cipta yang kerap dilakukan oleh para pembuat konten di media sosial adalah pemerintah harus segera membuat peraturan perundang-undangan yang secara spesifik dan efisien mengenai ketentuan hak cipta lagu di media sosial dalam kaitannya dengan hak ekonomi dan hak moral. Bahwa seiring dengan perkembangan zaman tidak dapat dipungkiri dengan kemudahan membuat konten di media sosial perlu diiringi dengan pembaharuan aturan yang mendampingi perilaku para pembuat konten dalam penggunaan lagu di media sosial. Penelitian ini juga memberikan gambaran bahwa kenyataanya para pelaku cover version kurang menyadari pentingnya menerapkan hak ekonomi dan hak moral ketika membuat konten di media sosial. Sehingga dibutuhkan upaya hukum yang seharusnya dilakukan oleh pihak pemerintah, para musisi dan juga masyarakat untuk bersama-sama meningkatkan apresiasi terhadap hak cipta lagu itu sendiri dengan tujuan meningkatkan iklim industri musik yang untuk kedepannya dapat berkembang.

\section{DAFTAR PUSTAKA}

Achmad, Atiekah, and Kholis Roisah. "Status Hukum Ghostwriter Dan Pemegang Hak Cipta Dalam Plagiarisme Menurut Undang-Undang Hak Cipta." Jurnal Magister Hukum Udayana (Udayana Master Law Journal) 9, no. 2 (2020): 429-47. https://doi.org/10.24843/JMHU.2020.v09.i02.p.15.

Aditya, I Gusti Putu Agung Angga, and Anak Agung Ketut Sukranatha. "Perlindungan Hak Terkait Sehubungan Dengan Cover Version Lagu Berdasarkan Undang-Undang Hak Cipta." Kertha Semaya: Journal Ilmu Hukum 7, no. 1 (2019): 1. https://doi.org/10.24843/km.2018.v07.i01.p07.

Aini, Fatimah Nurul, and Indirani Wauran. "Pemenuhan Prinsip Fair Use Dalam Cover Lagu Berdasar Hukum Hak Cipta Indonesia ( Fair Use Principles in Cover Song Based on Indonesian Copyright Law ) Abstrak," no. 28 (2021): 707-28. 
Akhmad, Munawar, and Effendy Taufik. "Upaya Penegakan Hukum Planggaran Hak Cpta Menurut Undang-Undang Nomor 28 Tahun 2014 Tentang Hak Cipta." Journal of Chemical Information and Modeling 53, no. 9 (2016): 1689-99.

Aldy Maldini. "Sedikit Video Keseruan Live Streaming Kemarin Di @bartspacejakarta Hehe Thank u Untuk Semua Yang Sudah Nonton Ya!!!!!” Instagram.com, 2021. https://www.instagram.com/p/CQYUseGhNwi/.

Ampuan, Situmeang, and Kusmayanti Rita. "Perlindungan Hukum Terhadap Pencipta Atau Pemegang Hak Cipta Lagu Dalam Pembayaran Royalti." Journal of Law and Policy Transformation 53, no. 9 (2020): 1689-99.

Amrikh Palupi. “Cover 'Akad` Diprotes, Hanin Dhiya Minta Maaf.” Dream.co.id, 2017. https://www.dream.co.id/showbiz/cover-akad-diprotes-hanin-dhiya-ucapkanpermohonan-maaf-171010u.html.

Aulia, M. Zulfa, and Isran Idris. "Hak Cipta Dan Eksploitasi Ciptaan Lagu Daerah Kerinci: Perspektif Pencipta." Masalah-Masalah Hukum 49, no. 4 (2020): 420-31. https://doi.org/10.14710/mmh.49.4.2020.420-431.

Awkarin. "That My Bestfriend." Instagram.com, 2021. https://www.instagram.com/p/CSYiAwxJ3-J/.

Dewa Gede Jeremy Zefanya, and A.A Sri Indrawati. "Cover Lagu Milik Musisi Indonesia" 8, no. 28 (2020): 1908-17.

Dimyati, Agus. "Tinjauan Yuridis Terhadap Perlindungan Hak Cipta Dalam Penggunaan Karya Cipta Musik Dan Lagu Karaoke." Hukum Responsif Jurnal Hukum 7, no. 1 (2018): 30-43.

Dirkareshza, Rianda, Dinda Maurizka Azura, and Roni Pradana. "Kebijakan Pemerintah Di Masa Pandemi Covid-19: Antara Negara Sejahtera Dan Negara Sehat." Jurnal $\begin{array}{lllll}\text { Mercatoria } & 1, & \text { no. } & 1 & \text { (2021): }\end{array}$ http://ojs.uma.ac.id/index.php/mercatoria/article/view/731/643.

Dwi Adriansyah, Muhammad. Pengaturan Pemberian Royalti Atas Hak Cipta Aransemen Lagu Di Indonesia Dan Amerika Serikat, 2021.

Fadhila, Ghaesany, and U. Sudjana. "Perlindungan Karya Cipta Lagu Dan/Atau Musik Yang Dinyanyikan Ulang (Cover Song) Di Jejaring Media Sosial Dikaitkan Dengan Hak Ekonomi Berdasarkan Undang-Undang Nomor 28 Tahun 2014 Tentang Hak Cipta." Acta Diurnal Jurnal Ilmu Hukum Kenotariatan Dan Ke-PPAT-An 1, no. 2 (2018): 222. https://doi.org/10.24198/acta.v1i2.117.

Habibi, Muh, Akbar Rusly, and Mukti Fajar Nd. "Mekanisme Pembayaran Royalti Lagu Dan Musik Dalam Aplikasi Streaming Musik" 1 (2020): 81-94. https://doi.org/10.18196/mls.v1i2.8344.

Kusno, Habi. "Perlindungan Hukum Hak Cipta Terhadap Pencipta Lagu Yang Diunduh Melalui Internet." FIAT JUSTISIA:Jurnal Ilmu Hukum 10, no. 3 (2017): 489-502. https://doi.org/10.25041/fiatjustisia.v10no3.789.

Muchtar, Henni. “Analisis Yuridis Normatif Sinkronisasi Peraturan Daerah Dengan Hak Asasi Manusia." Humanus 14, no. $1 \quad$ (2015): 80. https://doi.org/10.24036/jh.v14i1.5405.

Ningsih, Ayup Suran, and Balqis Hediyati Maharani. "Penegakan Hukum Hak Cipta Terhadap Pembajakan Film Secara Daring." Jurnal Meta-Yuridis 2, no. 1 (2019): 13-32. https://doi.org/http://dx.doi.org/10.26877/m-y.v2i1.3440.

Panjaitan, Hulman. “Akibat Hukum Penggunaan Karya Cipta Musik Dan Lagu Tanpa 
e-ISSN : 2621-4105

Izin.” To-Ra 6, no. 3 (2020): 290-301.

Pertiwi, Wahyunanda Kusuma. "TikTok Digugat Rp 13,1 Miliar Terkait Hak Cipta Lagu Virgoun."

https://tekno.kompas.com/read/2021/01/26/16140037/tiktok-digugat-rp-13-1miliar-terkait-hak-cipta-lagu-virgoun.

Pratista, I Gusti Putu Andre, and Ida Ayu Sukihana. "Pelanggaran Hak Moral Karya Lagu / Musik Dan Rekaman Suara Dalam Praktik Penggunaan Hak," n.d., 1-5.

Satria Dewi, Anak Agung Mirah. "Perlindungan Hukum Hak Cipta Terhadap Cover Version Lagu Di Youtube." Jurnal Magister Hukum Udayana (Udayana Master Law Journal) 6, no. 4 (2017): 508. https://doi.org/10.24843/jmhu.2017.v06.i04.p09.

Sinaga, J. “Jurnal Ilmiah Kebijakan Hukum.” Jurnal Ilmiah Kebijakan Hukum 10, no. 2 (2020): 1-209. 